Article

\title{
A Stakeholder Perspective of Port City Sustainable Development
}

\author{
Jasmine Siu Lee Lam ${ }^{1}$ and Wei Yim Yap ${ }^{2, *}$ \\ 1 Maritime Energy and Sustainable Development Centre of Excellence, School of Civil and Environmental \\ Engineering, Nanyang Technological University, Singapore 639798, Singapore; sllam@ntu.edu.sg \\ 2 School of Business, Singapore University of Social Sciences, Singapore 599494, Singapore \\ * Correspondence: wyyap@suss.edu.sg; Tel.: +65-6248-4473
}

Received: 12 October 2018; Accepted: 7 January 2019; Published: 16 January 2019

\begin{abstract}
As world seaborne trade continues to grow, especially in view of the Belt and Road Initiative (BRI), there is a mounting demand for a sustainable balance among the economic, social, and environmental performance of the port cities involved. This study aims to first conduct a review of existing sustainability frameworks; second, conduct a stakeholder analysis for port city sustainable development. The case studies of two major port cities in China-Guangzhou and Shenzhen, are conducted. According to the findings, a structured framework with main categories of economic, social and environmental indicators would be recommended for port cities. Dealing with diversified stakeholders and their interests is a major challenge for policy makers to overcome but opportunities do co-exist. Policy makers of Guangzhou and Shenzhen have made progress in balancing economic, social, and environmental interests in recent years. This study has taken a step forward in the research area, with a view to provide reference to stakeholders and governments in progressing towards sustainable development in port cities.
\end{abstract}

Keywords: port city; sustainable development; sustainability framework; stakeholder; Belt and Road Initiative

\section{Introduction}

In response to rising pressures from growing world population, increasing resource consumption, environmental degradation and climate change, there is a clear call for sustainable development in the world today in order to meet the United Nations' (UN) Millennium Development Goals. In the global context, progress towards sustainable development requires collective efforts from the public-at-large, corporate bodies, governments, and international bodies. For instance, the UN Conference on Sustainable Development (CSD) - RIO+20 Conference, held in June 2012, was an effort aiming to secure international commitments for sustainable development by focusing on developing green economies and improving the institutional framework for sustainable development [1].

In view of the Belt and Road Initiative (BRI), maritime trade and port activities are expected to grow $[2,3]$. This has led to a mounting demand for a sustainable balance among the economic, social and environmental performances of the port cities involved. This paper is devoted to this issue, and it presents a study on the sustainable development of port cities. Tan [4] describes port cities as centers of exchange of goods, people, information, and knowledge between different cultures and environments (Kidwai [5]; Driessen [6]). They serve as nodes in the network of international trade to facilitate economic growth, and they are influenced by their hinterland and foreland, the extent of which depends on political, economic, and social aspects (Tan [4]). Though sustainability can be achieved independently for the port and the city, as reported by Peris-Mora et al. [7], this paper looks at the collective sustainable development of a port city so that the influences and interactions between 
the port and the city are accounted for. The port and the city are not two separate entities, but they are interdependent, overlapping, and they influence each other, subject to the functions and type of port in the city (Fusco Girard [8]). In this context, sustainable development is primarily concerned with the development of the port infrastructure and superstructure. Port development drives and it is driven by the development of the city, to facilitate trade. Hence, port city sustainable development would refer to the development of a port and the city to meet the present and forecasted needs of various stakeholders (arising from port usage and trade) without compromising the ability of future generations to meet their own needs. This entails retaining existing port users and attracting new users by ensuring and maintaining a competitive advantage over competing ports in a sustainable way.

As discussed, various stakeholders' demands should be met in port city sustainable development. However, little research addressing this issue can be found from the literature. This study aims to first, conduct a review of sustainability frameworks, and second, to conduct a stakeholder analysis for port city sustainable development. After this introduction, these two objectives will be fulfilled by Sections 2 and 3, respectively. Section 4 presents two case studies. Section 5 concludes the paper.

\section{Review of Sustainability Frameworks}

According to the United Nations Conference on Trade and Development (UNCTAD), world seaborne trade continues to increase, driven by continued growth in world merchandise trade. As such, sustainable development has become pertinent to the maritime and port industries for supporting and facilitate this continued growth in trade by providing cargo-handling facilities, transshipment and other auxiliary services for ships without compromising on the environmental, social, or economic aspects. This is important as ports and their usage have significant impacts on the city, hinterlands, and forelands. Merk et al. [9] and Intervistas [10] describe how spending from port users, terminal operators, and port employees leads to direct and indirect multiplier effects on the economy, contributing to national GDP. Ports cause the agglomeration of economic activities in the city by attracting people and firms, such as distribution centers or warehouses, to be located in close proximity to ports to reduce transportation costs. Firms providing auxiliary maritime services such as ship agencies, ship financing firms, and third-party logistics providers would be attracted to operate near ports where shipping carriers call. Such kinds of agglomeration also contributes to economic growth and local employment in the city (Chen and Lam [11]). Agglomeration diseconomies, includes external social costs such as air, noise, and water pollution from port activities which affect the health and social well-being of the local inhabitants. Inland cargo transportation may put a strain on the inland transport infrastructure and cause traffic congestions (Merk et al. [9]). Thus, the sustainable development of a port city would require port development to integrate sustainability into their overarching development objectives and policies.

Several existing frameworks are available for sustainability assessment. A framework can be viewed as a structure that can be used to select relevant sustainable development indicators (SDIs) by identifying the information need for the stated purpose and it can aid the process of structuring information during reporting and communicating (Lundin [12]). A list of various types of sustainability frameworks is summarized and described in Table 1. A comparison of the existing frameworks in Table 1 is conducted to review their suitability in the context of a port-city sustainability framework. Driving force-state-response (DSR) and Pressure-state-response (PSR) frameworks contain ambiguity in categorizing indicators (CSD [13]), and some indicators have overlapping categories as well (Lundin [12]). Capital frameworks face limitations with substitutability between different types of capital and difficulty in expressing capital in monetary terms. Large indicator sets also result in cumbersome data collection. The System of Integrated Environmental and Economic Accounting (SEEA) framework does not encompass the social or institutional aspects as yet, while designing of questions under the Systems Analytical framework hinges largely on the expertise of the researchers.

Our evaluations have led to an assertion that it would be more appropriate to adopt a thematic framework where indicators of different themes are streamlined into three main categories-economic, 
social and environmental indicators. This is known as the Triple Bottom Line, commonly found in various sustainability studies (GRI [14]; CSD [13]; Warhurst [15]). The hierarchical framework used by the Global Reporting Initiative (GRI) is a good example. This Triple Bottom Line concept was incorporated into the 2002 Johannesburg Plan of Implementation (JPOI) to guide UN's efforts in sustainable development at national, regional, and international levels. Such a framework is also widely adopted in official national or regional indicator sets such as the Baltic 21 Action Programme, the Mediterranean Sustainable Development Strategy and Sustainable Development Indicators for the European Union. The multiple themes of indicators reflect the diverse factors that constitute sustainable development, and enable monitoring of progress towards goals and benchmarks (CSD [13]).

Table 1. Existing sustainability frameworks.

\begin{tabular}{|c|c|c|}
\hline Framework & Description & References \\
\hline $\begin{array}{l}\text { Driving force-state-response } \\
\text { (DSR)/Pressure- } \\
\text { state-response (PSR) } \\
\text { framework }\end{array}$ & $\begin{array}{l}\text { Human activities exert pressures on the environment, } \\
\text { causing changes in the state of the environment or the } \\
\text { quality and quantity of the resource by emissions and } \\
\text { consumption. Society then responds to these changes by } \\
\text { instituting policies, which feed back to mitigate the } \\
\text { pressures. It was adopted by the European Environmental } \\
\text { Agency (EEA) and the European Statistical Office in } 1997 .\end{array}$ & $\begin{array}{l}\text { (OECD [16]); } \\
\text { (CSD [13]); } \\
\text { (Lundin [12]); } \\
\text { (Singh, Murty, Gupta \& } \\
\text { Dikshit [17]) }\end{array}$ \\
\hline Theme Framework & $\begin{array}{l}\text { A thematic framework compiles a comprehensive list of } \\
\text { indicators from different themes or issues related to } \\
\text { sustainability. It allows for the monitoring of progress } \\
\text { towards goals, and is flexible to adjust indicator sets to new } \\
\text { policies. }\end{array}$ & (Lundin [12]); (CSD [13]) \\
\hline Capital Frameworks & $\begin{array}{l}\text { Calculates national wealth as a function of the sum of and } \\
\text { interaction among different kinds of capital including } \\
\text { financial capital, produced capital goods, natural, human, } \\
\text { social, and institutional capital expressed in monetary terms. }\end{array}$ & $(\mathrm{CSD}[13])$ \\
\hline $\begin{array}{l}\text { Systems Analytical } \\
\text { Framework }\end{array}$ & $\begin{array}{l}\text { Sustainable development indicators (SDIs) are chosen based } \\
\text { on their ability to provide answers to a set of questions with } \\
\text { regard to sustainability of a system. }\end{array}$ & (Lundin [12]); (Bossel [18]) \\
\hline $\begin{array}{l}\text { System of Integrated } \\
\text { Environmental and Economic } \\
\text { Accounting (SEEA) } \\
\text { Framework }\end{array}$ & $\begin{array}{l}\text { Pioneered by various international bodies (United Nations } \\
\text { Statistical Commission with the International Monetary } \\
\text { Fund, the World Bank, the European Commission and } \\
\text { OECD), the SEEA allows for the construction of a common } \\
\text { database from which common SDIs in economic and } \\
\text { environmental aspects can be derived consistently. }\end{array}$ & $\begin{array}{l}\text { (UN Statistics Division } \\
\text { [19]) (CSD [13]) }\end{array}$ \\
\hline $\begin{array}{l}\text { Global Reporting } \\
\text { Initiative (GRI) }\end{array}$ & $\begin{array}{l}\text { The GRI (launched in } 1997 \text { by the United Nations } \\
\text { Environment Programme (UNEP) and United States NGO, } \\
\text { Coalition for Environmentally Responsible Economics } \\
\text { (CERES)) was launched with the aim to enhance the 'quality, } \\
\text { rigor and utility of sustainability reporting.' The GRI uses a } \\
\text { hierarchical framework in three areas-social, economic, and } \\
\text { environment. }\end{array}$ & $\begin{array}{l}\text { (GRI [14]), (Singh, Murty, } \\
\text { Gupta \& Dikshit [17]) }\end{array}$ \\
\hline $\begin{array}{l}\text { Systems framework for } \\
\text { port city }\end{array}$ & $\begin{array}{l}\text { Uses a hierarchical framework in three areas-social, } \\
\text { economic, and environment, for a port system and a city } \\
\text { system in an integrative manner such that port-city } \\
\text { relationships can be evaluated holistically. }\end{array}$ & (Xiao \& Lam [20]) \\
\hline
\end{tabular}

Source: Compiled by authors.

Existing sustainability studies, such as the GRI, Millennium Development Goals Indicators (MDG, [14]), Sustainable Development Goals from United Nations Conference on Sustainable Development (CSD [13]) and OECD Key Environmental Indicators (OECD [21]) amongst others, are largely suitable for assessment at a national or regional level, but they are lacking in relevance for the involvement of corporate stakeholders in a port city, who play an important role in sustainability. Therefore, a gap exists, which motivates the need for a stakeholder analysis. Furthermore, the sustainability frameworks as shown in Table 1 have limitations for the reason that they are generic, except for the last one, which is specifically for port cities. Xiao and Lam [20] propose a systems framework for port city sustainable development. This framework also adopts a Triple Bottom Line hierarchical structure. It includes overall criteria and sub-criteria for a port system and a city system in 
an integrative manner such that port-city relationships can be assessed holistically. Thus, the systems framework will be deployed in our analysis.

\section{Research Methodology}

This paper conducts a stakeholder analysis by the case study method. A stakeholder is one who has an identifiable interest or stake in a policy being passed (Schmeer [22]). Stakeholder analysis, according to The World Bank (Swanson [23]), is used to account for various stakeholders' needs, in order to develop sustainable and feasible policies. Referring to Dooms et al. [24] and Ravesteijn et al. [25], stakeholder management is important for infrastructure development, and stakeholder identification is the first step. At a generic, higher level, key stakeholders in port cities and their objectives were analyzed. Then, we conducted real-life case studies for the benefit of having in-depth analysis (Yin [26,27]). The case study approach was desirable for tackling this research problem, because we could investigate stakeholders' involvement in a port city through its development path. The chronological port city development data and information were collected and processed.

Two port cities in South China-Guangzhou and Shenzhen, were chosen as case studies because of three criteria: a port city's association with the study scope of BRI, comparable geographical location, and significant size. Both Guangzhou and Shenzhen were targeted to connect to the BRI as their major goal. Both port cities are located in the south of Guangdong province, and the two ports are among the busiest Chinese ports. Therefore, they fit the study scope very well, and it is interesting to find out the similarities and differences between them with regards to port city sustainable development.

Secondary data and information sources are gathered from academic literature, official reports, news, market reports, ports, and other websites. Both Chinese and English sources were approached, in order to ensure sufficient coverage. These data and information were firstly screened, and then classified into economic, social, and environmental aspects according to the definition of sustainable development [13].

\section{Stakeholder Identification and Objectives}

According to the stakeholder theory [28], stakeholders are affected by externalities generated by entities, and in turn stakeholders exert influences on these entities to mitigate negative externalities. For port city sustainable development, it is important to identify key stakeholders and the objectives that they look for. This section offers analyses focusing on port city stakeholders.

With reference to Coppens et al. [29] and Lam et al. [30], the various stakeholders unique to a port city are identified in Table 2 . This stakeholder analysis highlights the level of influence that stakeholders have to effect reforms towards sustainable development. There are four groups of stakeholders, namely, internal stakeholders, the public sector, market players/corporate bodies, and community/interest groups. Except for the last group, the other three groups contain stakeholders who are decision-makers in port city development matters at various authoritative levels. The stakeholders come from very diverse backgrounds, ranging from port owners to logistics companies. It means that decision-making is a complex process, with multiple interests confronted and hopefully resolved.

Conflicts exist when port owners, port managers, and market players, who are usually profit-driven, target for economic prosperity aggressively, which compromises social wellbeing and the environment. Therefore, they are in conflict with port employees and community groups. In particular, port employees and community groups are not usually the decision makers in port city development matters or policies, and their voices may be under-represented or even unheard. A stakeholder management approach should rightfully balance the economic, social, and environment aspects. 
Table 2. Summary of stakeholder identification.

\begin{tabular}{llc}
\hline \multicolumn{1}{c}{ Nature of Stakeholder } & \multicolumn{1}{c}{ Key Stakeholders in Port Cities } & $\begin{array}{c}\text { Decision-Makers: Yes } \\
\text { (Y) or No (N) }\end{array}$ \\
\hline \multirow{3}{*}{ Internal } & $\begin{array}{l}\text { Port employees, minority shareholders } \\
\text { Port managers, board members } \\
\text { Owners of ports e.g., government/port operator; } \\
\text { port regulator }\end{array}$ & $\mathrm{N}$ \\
\hline & $\begin{array}{l}\text { Port authority; port state control } \\
\text { National governments; ministries-in-concern e.g., } \\
\text { Transport Ministry, Finance Ministry, Environment }\end{array}$ & $\mathrm{Y}$ \\
& $\begin{array}{l}\text { Ministry, legislators, urban development authorities } \\
\text { Lublic Sector }\end{array}$ & \\
\hline \multirow{2}{*}{$\begin{array}{l}\text { Labor unions } \\
\text { bodies }\end{array}$} & $\begin{array}{l}\text { Stakeholder organizations: inland and sea transport } \\
\text { operators, logistics company, shipping and transport } \\
\text { companies, Stevedoring companies }\end{array}$ \\
\hline \multirow{2}{*}{$\begin{array}{l}\text { Community; } \\
\text { Interest Groups }\end{array}$} & $\begin{array}{l}\text { Local inhabitants living in close proximity to ports } \\
\text { Consumers and tax-payers } \\
\text { Non-profit organizations (NGOs) e.g., } \\
\text { environmental groups }\end{array}$ \\
\hline Media, press
\end{tabular}

Source: Authors.

After identifying the key stakeholders, their needs, values, and objectives are analyzed based on a review of the literature and sustainability reports of major port cities (by cargo and shipping tonnage), such as Shanghai and Singapore [31,32], as shown in Table 3. The stakeholder objectives are divided into two levels: (1) Corporate level, which will be useful for individual companies or organizations, (2) National/Multi-national level, which will be useful for governments and government-linked units. It is important to note that such needs vary with governments, cultures, company policies, and strategies. Hence, the analysis is not meant for a one-size-fit-all solution, but a high level guideline that would be helpful for each port city for further development. Resolutions for conflicting stakeholders should be aligned to the overarching objective of achieving sustainable development. The diversity of stakeholder and user groups with different objectives and needs requires that the core group of the indicators selected have sufficient flexibility to be tailored to specific user's needs.

Table 3. Stakeholder objectives for sustainable development indicators (SDIs).

\begin{tabular}{ll}
\hline \multicolumn{1}{c}{ Corporate Level Objectives for SDIs } & \multicolumn{1}{c}{ National/Multi-National Objectives for SDIs } \\
\hline $\begin{array}{l}\text { Assess organizational performance towards } \\
\text { sustainability. }\end{array}$ & $\begin{array}{l}\text { Ensure the competitiveness of the port city to boost } \\
\text { economic growth and trade }\end{array}$ \\
\hline $\begin{array}{l}\text { Compare sustainability performance with different } \\
\text { organizations over time. }\end{array}$ & $\begin{array}{l}\text { Benchmarking to port performance standards, codes, } \\
\text { or laws. }\end{array}$ \\
\hline Benchmarking purposes. & $\begin{array}{l}\text { Promote closer collaboration between government } \\
\text { authorities and the private sector to promote } \\
\text { sustainability. }\end{array}$ \\
\hline $\begin{array}{l}\text { Identify areas for improvements in work processes } \\
\text { towards sustainability. }\end{array}$ & Comparability across similar port cities. \\
\hline
\end{tabular}

Source: Authors.

Prior to adopting frameworks and indicator sets, a clear definition of policy goals towards sustainability is needed (Lundin [12]). As such, SDIs selected should fulfill the criteria listed in Table 3, to ensure their applicability to stakeholders.

\section{Case Studies of Guangzhou and Shenzhen}

\subsection{Guangzhou}

A background of Guangzhou is provided here. Guangzhou city is the capital, and most populous city of Guangdong province where the city center is located in Tianhe district. Guangzhou port is the 
largest comprehensive port in South China, and it acts as a major transportation hub today. It ranked third (in 2016) (AAPA [33]) and the seventh (in 2016 and 2017) (JOC [34]) in the world, in terms of total cargo volume handled and total container throughput, respectively. The port of Guangzhou consists of four major terminal areas, Neigang, Huangpu, Xinsha and Nansha, and the Pearl River Estuary Anchorage (see Figure 1). The port handles a wide range of marine cargoes, from energy products, raw materials, and dry bulk, to containers. The total cargo throughput was about 570 million tons in 2017, with a year-to-year growth rate of $9.09 \%$ from 2016, and an average annual growth rate of $5.55 \%$ from 2012. The port handled over 20 million twenty-foot-equivalent units (TEUs) of containers in 2017, with a year-to-year growth rate of $8.18 \%$ from 2016 , and an average annual growth rate of $6.72 \%$ from 2012, as shown in Table 4.

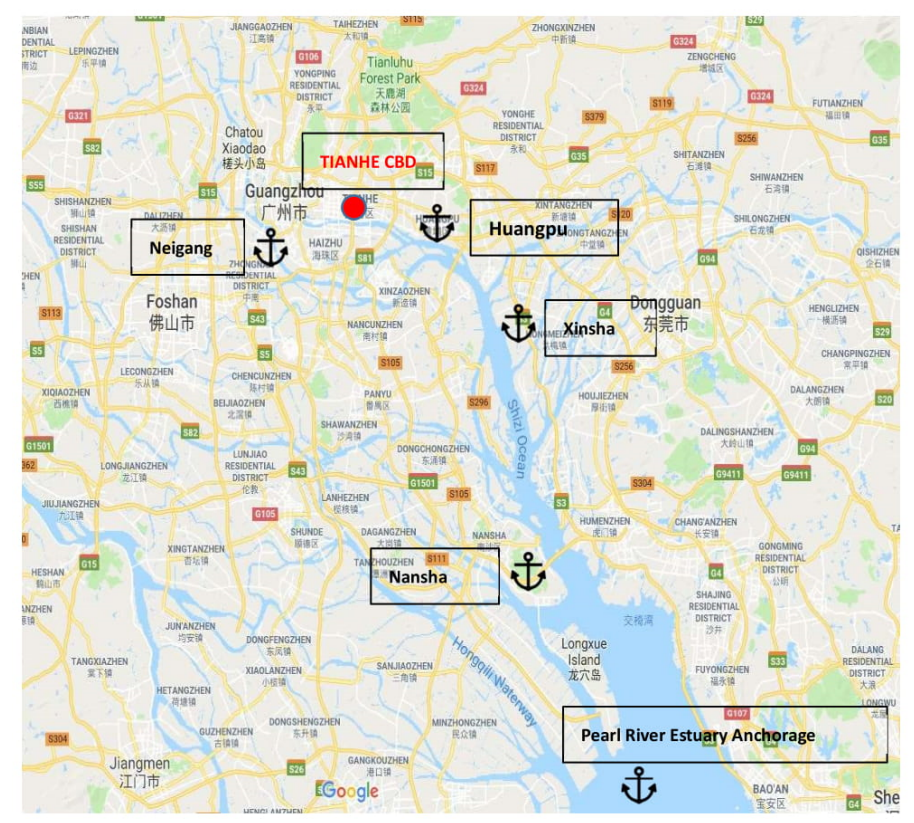

Figure 1. Overview of Guangzhou port city. Source: Authors.

Table 4. Port of Guangzhou: Cargo throughput and growth rate.

\begin{tabular}{ccccccc}
\hline Year & $\begin{array}{c}\text { Freight } \\
\text { Throughput (Ton) }\end{array}$ & $\begin{array}{c}\text { Annual } \\
\text { Growth } \\
\text { Rate } \\
\mathbf{( 2 0 1 2 - 2 0 1 7 )}\end{array}$ & $\begin{array}{c}\text { Annual } \\
\text { Growth } \\
\text { Rate } \\
\mathbf{( 2 0 1 6 - 2 0 1 7 )}\end{array}$ & $\begin{array}{c}\text { Container } \\
\text { Throughput } \\
\text { (TEU) }\end{array}$ & $\begin{array}{c}\text { Annual } \\
\text { Growth } \\
\text { Rate } \\
(\mathbf{2 0 1 2}-2017)\end{array}$ & $\begin{array}{c}\text { Annual } \\
\text { Growth } \\
\text { Rate } \\
\mathbf{( 2 0 1 6 - 2 0 1 7 )}\end{array}$ \\
\hline 2012 & $435,170,000$ & & & $14,522,460$ & & \\
2016 & $522,540,000$ & $5.55 \%$ & $9.09 \%$ & $18,580,000$ & $6.72 \%$ & $8.18 \%$ \\
2017 & $570,030,000$ & & & $20,100,000$ & & \\
\hline
\end{tabular}

Source: Authors, compiled and calculated based on data from CEIC database- China Premium Database.

We analyze Guangzhou port city's development path together with stakeholders' roles and objectives. Guangzhou was already a major terminus of the traditional Maritime Silk Road (MSR) during the ancient times. In the contemporary era, during years 1991 to 2000, its emergence was triggered by the growth of development zones in China, promoting an export-oriented economy (Wang and Slack [35]). Nowadays, the port city of Guangzhou serves as an important commercial and transport center for the Pearl River Delta region and Guangdong province, as well as other industries located in neighboring provinces. Our analysis of urban economic structure in Guangzhou shows that the development of Guangzhou port is greatly influenced by the urban economic structure of Guangzhou city, mainly reflected in the changes in industrial structure and the economic characteristics. In terms of stakeholders, this reflects that the needs from market players and community groups (especially local residents) are being met. The energy consumption structure in Guangzhou city is relatively simple, based mainly on coal, liquefied gas, and natural gas. The increase in energy 
consumption has led to a considerable growth of the throughput proportion of coal, coal products, oil, natural gas, and other petroleum products among all other cargo types. It is similar for the growth of construction materials (including steel and mineral products), due to the development of the construction industry in Guangzhou.

From year 2001 to 2010, Guangzhou has grown rapidly in tandem with Pearl River Delta's economic growth. In terms of stakeholders, much is attributable to the efforts of public policy makers in driving Guangzhou's development. The Chinese government, which involves Guangzhou Municipal People's Government and Guangzhou Port Administration Bureau, proactively developed Guangzhou port city. Strategic plans were put forth to expand and upgrade port functions, develop port-oriented industries, so as to transform Guangzhou from a river port to a coastal port and become a port-based economy. Also, internal stakeholders, especially Guangzhou Port Group Company Limited (a state-owned enterprise) play an important role in port operations and management. There was huge investment (over 10 billion RMB) for Guangzhou port development, including the construction of new berths, deepening and widening of the sea channel, strengthening of container terminals and oil/petroleum terminals, upgrading of coal and grain handling systems and other facilities to fundamentally improve the standard and strategic functions of Guangzhou port.

The port of Guangzhou has become the largest transhipment hub for energy products, foodstuff, raw materials, etc., in South China. It is the distribution center for fuel and food processing materials in the Pearl River Delta region. Guangzhou city has leveraged on the port industry to develop other port-based industries and to adjust the port-based industrial structure, which could promote further the overall economy. Large-scale petroleum products and coal trading center and grain trading center have been built in Guangzhou. Automobile Manufacturing Bases, Steel Base, and other port-oriented industrial bases have been completed and put into operation in Guangzhou city. All these have gradually developed into Guangzhou Development Zone-Port Industrial Zone, and Port Industrial Zones of Nansha and Xinsha.

While the economy of Guangzhou continues to grow, sustainability issues have increasingly surfaced in this decade. The local community is primarily concerned about how ship emissions and polluted waters in Port of Guangzhou can possibly affect their health and water consumption. Environmental groups are concerned about how the rapid growth of the port city and adjacent industries would harm the environment, such as carbon emissions leading to global warming and climate change. From 2011 to 2018 (the time of writing this article), Guangzhou has stepped forward to the phase of sustainable development. Public policy makers are leading this effort to address economic, social, and environmental interests.

The latest 13th Five-Year Plan of the port (2016-2020) embraces the concept of clustering, and it has indicated the development direction for Guangzhou, to benchmark with the world's most advanced international maritime centers. The mission is to cultivate a modern shipping service system, and to improve the shipping logistics system on the basis of strengthened port and terminal infrastructures and the multimodal transport system, with the aim of enhancing connectivity with other ports along the 21st century MSR. Establishing a green and safe port, a smart shipping system, and open port relationships with other ports are part of the entire plan of promoting Guangzhou as an international maritime center (Guangzhou Port Authority, [36]). To address social and environmental concerns, for example, there is an emission control area. The exhaust gas emitted by vessels while at berth in Guangzhou port is restricted to a sulfur content of not less than $0.5 \% \mathrm{~m} / \mathrm{m}$. In addition to the use of low-sulfur bunkers by ships, Guangzhou targets to have $50 \%$ of their terminals to be equipped with onshore power supply (also called cold ironing) facilities by 2020 (Guangzhou Port Authority, [36]). The draft of the latest Guangzhou City Master Plan (2017-2035) was completed in early 2018. The draft plan has proposed the construction and development of a world-class airport, seaport, and railway hub. By 2035, the port of Guangzhou is projected to handle 36 million-TEU containers annually, and 750 million tons marine cargoes in total. Guangzhou city will also explore the construction of free 
trade ports in Nansha, Huangpu and Airport Economic Zones to the highest international standard (Guangzhou city [37]) Guangzhou port city's development path is summarized in Figure 2.

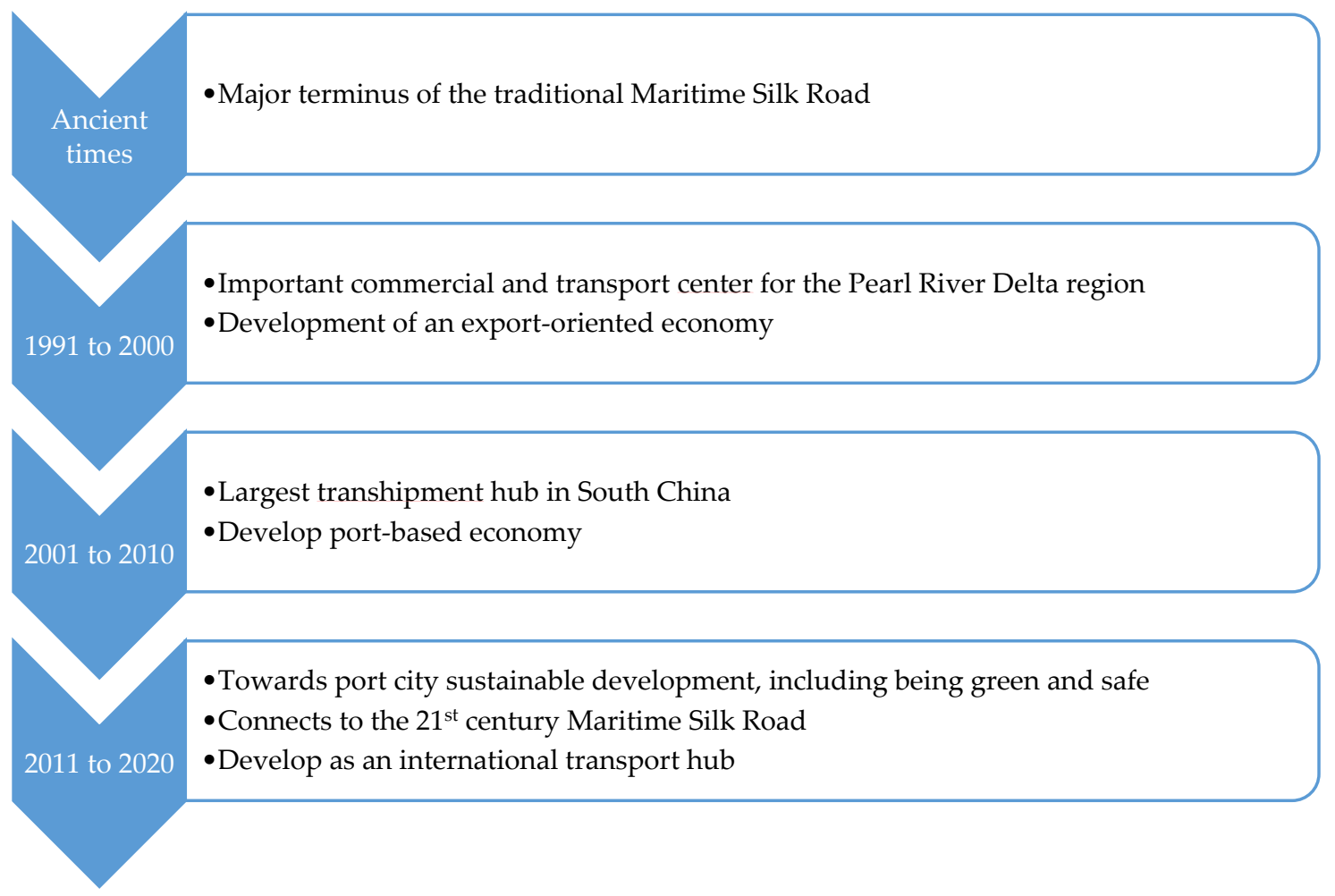

Figure 2. Guangzhou port city's development path. Source: Drawn by authors.

\subsection{Shenzhen}

Shenzhen is another major port city in the Pearl River Delta region. It is an important transportation hub in the coastal areas of South China, playing a significant role in China's high-technology industries, financial services, foreign trade, and maritime transportation. Shenzhen seaport ranked the 19th (in 2016) (AAPA [33]) and the third (in 2016 and 2017) (JOC [34]) in the world, in terms of total cargo volume handled and total container throughput, respectively.

The city center or central business district (CBD) of Shenzhen is called Futian. The port of Shenzhen consists of facilities in 10 terminal areas: Shekou, Chiwan, Mawan, Yantian, Dachanwan, Shayuchong, Xiadong, Dongjiaotou, Fuyong, and Neihe (see Figure 3). The port handles a variety of marine cargoes, ranging from oil, petroleum products, dry bulk, to containers. The total cargo throughput was about 237.6 million tons in 2017, with a year-to-year growth rate of $10.98 \%$ from 2016, and an average annual growth rate of $0.66 \%$ from 2012. Regarding container throughput, the port handled over 25 million TEUs in 2017, with a year-to-year growth rate of 4.59\% from 2016 and an average annual growth rate of $1.82 \%$ from 2012 (see Table 5). 


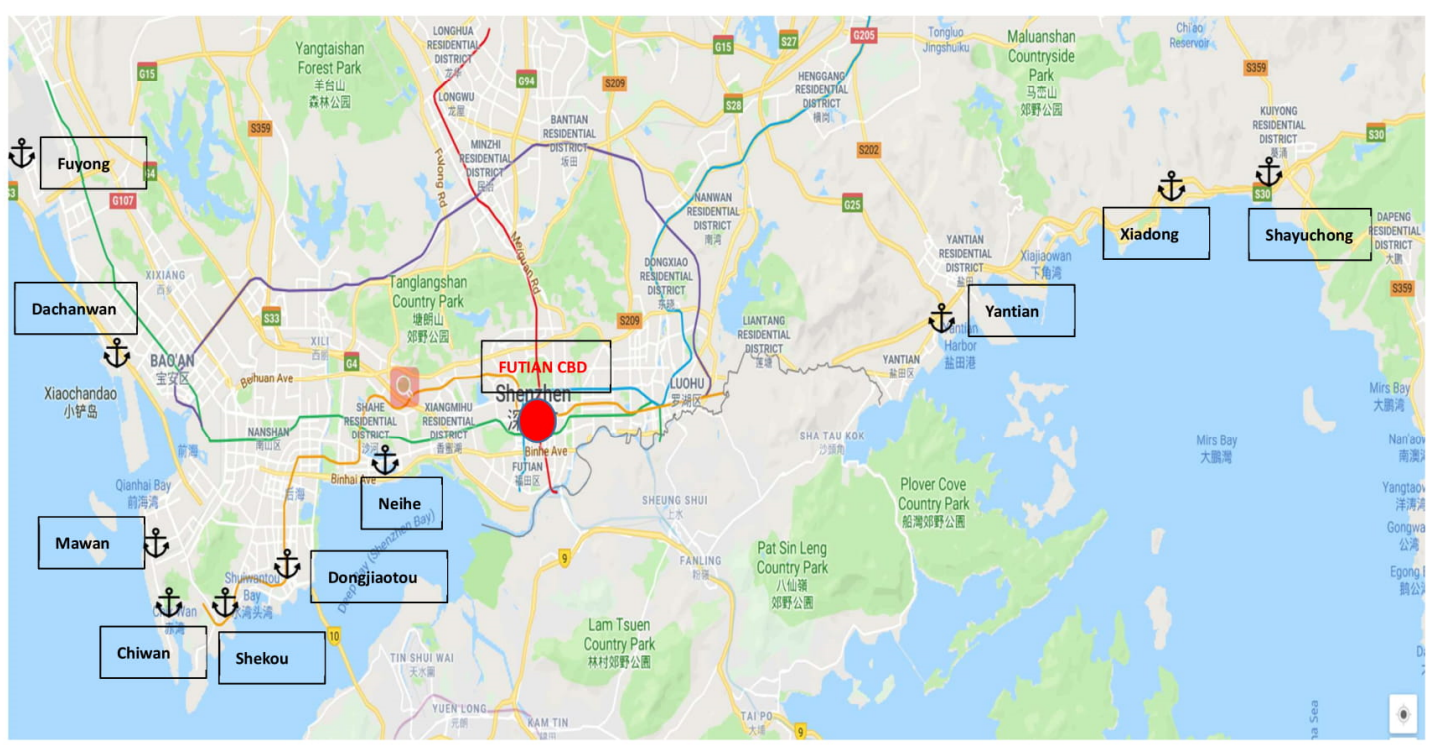

Figure 3. Overview of Shenzhen port city. Source: Authors.

Table 5. Port of Shenzhen: cargo throughput and growth rate.

\begin{tabular}{ccccccc}
\hline Year & $\begin{array}{c}\text { Freight } \\
\text { Throughput (Ton) }\end{array}$ & $\begin{array}{c}\text { Annual } \\
\text { Growth } \\
\text { Rate } \\
(\mathbf{2 0 1 2 - 2 0 1 7 )}\end{array}$ & $\begin{array}{c}\text { Annual } \\
\text { Growth } \\
\text { Rate } \\
\mathbf{( 2 0 1 6 - 2 0 1 7 )}\end{array}$ & $\begin{array}{c}\text { Container } \\
\text { Throughput } \\
\text { (TEU) }\end{array}$ & $\begin{array}{c}\text { Annual } \\
\text { Growth } \\
\text { Rate } \\
(\mathbf{2 0 1 2 - 2 0 1 7 )}\end{array}$ & $\begin{array}{c}\text { Annual } \\
\text { Growth } \\
\text { Rate } \\
\mathbf{( 2 0 1 6 - 2 0 1 7 )}\end{array}$ \\
\hline 2012 & $229,881,600$ & & & $22,930,790$ & & \\
2016 & $214,110,000$ & $0.66 \%$ & $10.98 \%$ & $23,998,500$ & $1.82 \%$ & $4.59 \%$ \\
2017 & $237,617,900$ & & & $25,099,710$ & & \\
\hline
\end{tabular}

Source: Authors, compiled and calculated based on data from the CEIC database-China Premium Database.

By a similar approach, this case study also analyses Shenzhen port city's development path together with stakeholders' roles and objectives. It used to be a very small town adjacent to Hong Kong serving as a cross-border point between Hong Kong and Mainland China. The year 1979 was the turning point, as Shenzhen was made a Special Economic Zone by the Chinese government. There was an influx of foreign investment and economic activities started to pick up. From 1991 to 2000, the Pearl River Delta region experienced a strong growth in manufacturing. Correspondingly, the port of Shenzhen acted as a major port for facilitating imports and exports, and it grew rapidly. At the same time, there was fierce competition between the ports of Shenzhen and Hong Kong (Lam and Yap [38]). With regards to stakeholders, internal stakeholders (e.g., terminal operating companies) and market players (e.g., logistics service providers) enjoyed economic benefits at large as reflected by financial gains of enterprises.

In the period of 2001 to 2010, Shenzhen continued to develop rapidly till the time of global economic recession in 2008. Integrated and strategic port city planning became important for the next phase of growth. During 2003-2005, the Shenzhen Municipal Planning Bureau and China Urban Planning and Design Institute jointly completed the "Shenzhen 2030 Urban Development Strategy" (also known as Shenzhen 2030). It is strongly forward-looking and a significant guiding force for both the country and Shenzhen in the period of strategic transformation. It determines that the functional positioning of Shenzhen's urban development in the future, which includes a logistics hub city in relation to maritime transportation and seaport development. Under this urban development strategy, the western coastal area is planned to develop a modern logistics industry with its combined advantages of large transportation infrastructure such as ports, airports, and expressways. The eastern region is planned to develop an international port logistics industry, with its supporting business in trading and warehousing, with Yantian district focusing on deep-water ports as a pillar industry (Huang [39]). The overall focus is mainly on economic prosperity. 
From 2011 to 2017, the growth of the cargo volume has stalled after many years of increase in the previous two decades (see Table 5). It is noted that container throughput dropped from 24,142,000 TEUs in 2015 to 23,998,500 TEUs. In addition to the mega-trend of economic slowdown, some manufacturers moved their factories to inland China due to rising labor, rental, and logistics costs in the Pearl River Delta region. The stakeholders of Shenzhen port city have common interests for enhance its competitiveness. The government is the key driver in driving new initiatives. As of now, the port of Shenzhen has already become an important port in international shipping. For Shenzhen to develop sustainably, it is gradually extending its port supply chain to integrate the resources of the port and the hinterland logistics park, to promote the port and the logistics park from the lower end of the value chain to a higher end of the value chain. Yantian Port Bonded Logistics Park and Qianhai Bay Bonded Port Area are good examples of the measures taken to actively adapt to the market demand, expand logistics functions and to improve service levels. In addition, according to another strategic development plan, the "Outline of the Reform and Development Plan of the Pearl River Delta Region (2008 2020)" (National Development and Reform Committee [40]), the Shenzhen-Zhongshan Bridge could be completed by 2024. It should then greatly facilitate the logistics flow from the west bank of the Pearl River to reach the terminals in Shenzhen.

Similar to Guangzhou, sustainability issues have emerged as Shenzhen grows. Marine pollution and exhaust gas emissions pose a threat to residents who live near the port, causing adverse social and ecological impacts. Also, there is severe competition in land, housing, and many other types of resources. The conditions of traffic and human congestion have deteriorated. For the port city's sustainable development, it is vital to address these concerns to ensure that different stakeholders' interests are attended. The latest 13th Five-Year Plan (2016-2020) has indicated that the development direction for Shenzhen port city with sustainability elements. Among the identified schemes, the development of Shenzhen as an international shipping hub connecting in the BRI is the overall goal. The plan proposes to further strengthens the deep-water strategy for development of Shenzhen, to enhance the construction of inland and sea corridors, and to focus on improving shipping infrastructures and the service standard, and to build smart ports and low-carbon green ports. Shenzhen and Guangzhou are in the same emission control areas. The exhaust gas emitted by vessels while at berth in Shenzhen port is also restricted to a sulfur content of less than $0.5 \% \mathrm{~m} / \mathrm{m}$. The government drives the green effort by providing subsidies for onshore power supply to terminal operators and low-sulfur bunkers to ship operators. For instance, subsidies amounting to 6.55 million RMB was given in the fourth quarter of 2016 (Shenzhen Municipal Transportation Committee [41]). Shenzhen city will also promote the establishment of a world-class container hub, through waterway engineering, further berth construction, and modification. By 2020, the port aims to achieve a container throughput of 28 million TEUs (Shenzhen Municipal Transportation Committee [35]). Shenzhen port city's development path is summarized in Figure 4. 


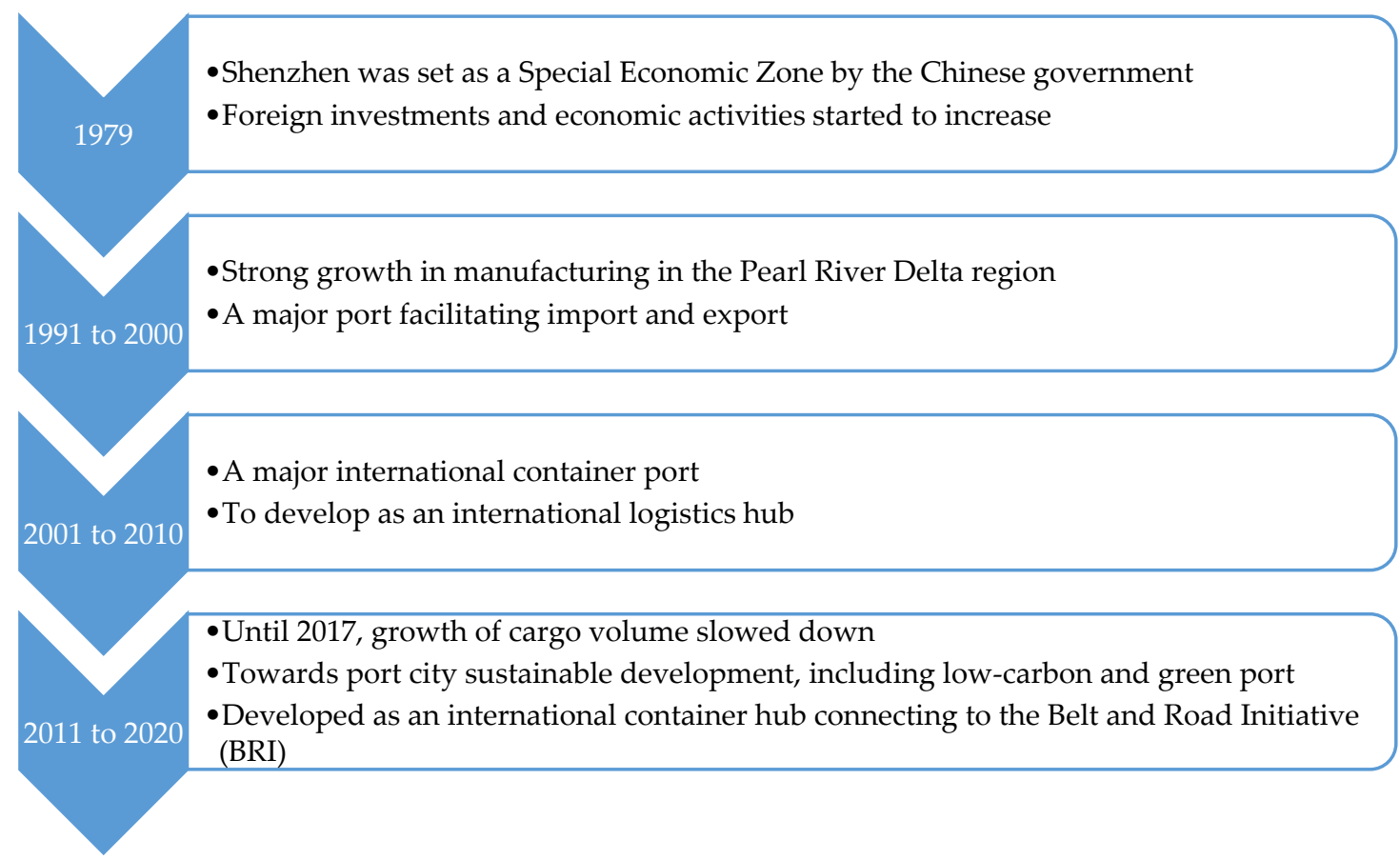

Figure 4. Shenzhen port city's development path. Source: Drawn by authors.

\subsection{Comparison between Guangzhou and Shenzhen}

Based on the above discussion, we can derive that the stakeholder objectives for SDIs in the cases of Guangzhou and Shenzhen are aligned with the finding in Table 3. In particular, the national objective for SDI of both Guangzhou and Shenzhen includes an enhancement of the competitiveness of the port city, to boost economic growth and trade. Both port cities ride on the opportunities offered by the BRI. In their long-term plans, there are efforts in improving social and environmental performances in recent years, but the economic aspect is given more weight. Different from Guangzhou, Shenzhen builds on its strength to further promote its status as an international container hub. Guangzhou handles a much higher volume of other cargoes, like dry bulk and liquid cargo. It tends to strategize more on a wider range of services, aspiring to be an international maritime center. As in Table 3, Guangzhou benchmarks itself with other port cities and international maritime centers. Benchmarking dimensions tend to put more emphasis on the economic aspect, but social and environmental performances are also included. Due to their geographical proximity and similarities as mentioned, it could be that Guangzhou and Shenzhen refer to each other as benchmarks.

With reference to the development path and the systems framework for port city [20], our study draws implications on the key challenges and opportunities that are faced by the two port cities. First, in terms of the economic aspect, the BRI provides vast opportunities in trade growth. However, other port cities such as Hong Kong also aim to be a key hub in BRI, so that the competition is expected to be intense. To strengthen the port city's competitiveness, Guangzhou and Shenzhen have improved on infrastructure and facilities to increase cargo handling and labor productivity over the years as shown by their Five-Year Plan 2016-2020. Looking forward, it would be challenging to further enhance productivity when development is mature, but opportunities arise when new technology is used to increase the productivity, e.g., new designs of automated stacking cranes and other types of automated cargo handling equipment [42].

Second, regarding the social aspect, coastal land occupation is a key sustainable development indicator for port cities, due to the limited availability coastal land for seaport terminals and city waterfront developments. A common challenge for both Guangzhou and Shenzhen is competition in land use by the port and the city, especially they are characterized by dense population. The port and 
the city interacts, leading to a challenging target of having enjoyable working and living conditions [43]. It is important to optimize coastal land use for sustainable development objectives including the reduction of congestion. Both Guangzhou and Shenzhen strive to further enhance the development of industrial and logistics zones. This can be an opportunity to integrate hinterland logistics to optimize transport corridors connecting seaport terminals. The overall direction will be in line with the aim of upgrading the port city status as an international transport cluster [44]. Another area of social sustainability is the safety level of the workplace. There is a tradeoff between the safety level and the attempt to increase trade volume and productivity. Nevertheless, smart technology does not only improve productivity, but also safety, thanks to higher precision. Together with proper staff training, it is possible to be a productive, safe and smart port.

Third, the environmental performance of a port city is reflected by pollution such as water pollution and air pollution. It is a common challenge to eliminate or minimize these pollutions, along with a growth strategy by the two port cities to increase ship traffic and cargo operations. However, there are opportunities given by the use of new managerial accounting instruments like the Balanced Scorecard to enhance the monitoring and measurement of pollution standards $[45,46]$. For example, the combination of incentive pricing for port dues to encourage high environmental standards beyond regulatory controls and penalty for generating pollution would be effective. In addition, new opportunities arise in terms of combating exhaust emission when ship operators within the port limit and terminal operators deploy cleaner fuels such as low-sulfur fuel, liquefied natural gas, and electrification. Table 6 summarizes the key challenges and opportunities of Guangzhou and Shenzhen.

Table 6. Key challenges and opportunities faced by the port cities Guangzhou and Shenzhen.

\begin{tabular}{|c|c|c|c|}
\hline \multirow{2}{*}{ Aspect } & \multirow{2}{*}{ Examples of SDI } & \multicolumn{2}{|c|}{ Key Challenges and Opportunities } \\
\hline & & Challenges & Opportunities \\
\hline \multirow[b]{2}{*}{ Economic } & Trade growth & Competition with other port cities & To be a key port city in BRI \\
\hline & $\begin{array}{l}\text { Cargo handling and } \\
\text { labor productivity }\end{array}$ & $\begin{array}{l}\text { More difficult to enhance } \\
\text { productivity when development is } \\
\text { mature }\end{array}$ & $\begin{array}{l}\text { Using smart technology to } \\
\text { increase productivity }\end{array}$ \\
\hline \multirow[b]{2}{*}{ Social } & Coastal land occupation & Competition in land use & Integrate hinterland logistics \\
\hline & Safety level & $\begin{array}{l}\text { Strive to increase volume and } \\
\text { productivity }\end{array}$ & $\begin{array}{l}\text { Using smart technology to } \\
\text { increase safety level }\end{array}$ \\
\hline \multirow{2}{*}{ Environmental } & Water pollution & Increase in ship traffic & $\begin{array}{c}\text { New managerial accounting } \\
\text { instruments }\end{array}$ \\
\hline & Air pollution & $\begin{array}{c}\text { Increase in ship traffic and cargo } \\
\text { operations }\end{array}$ & Deploying cleaner fuel \\
\hline
\end{tabular}

Source: Authors.

References can also be taken from the concept of the fifth-generation ports (5GP). As developed by Lee et al. [47], the five aspects of a 5GP are service, technology, sustainable development, cluster, and hub. In our analysis of their development path, Guangzhou and Shenzhen are geared towards these five aspects. Policy makers are recommended to consider a holistic set of criteria in 5GP for port city sustainable development.

\section{Conclusions}

In this study, existing sustainability frameworks were reviewed and evaluated. It was derived that a structured framework with main categories of economic, social and environmental indicators would be recommended for port cities. Also, this paper completed a key stakeholder identification and analyzed stakeholder's objectives for port cities as an original contribution. One should appreciate the diversity involved in stakeholder participation. Policy-making would be challenging due to the different interests of multiple stakeholders, but opportunities also co-exist. Stakeholder engagement is an essential step for minimizing conflicts and for approaching win-win strategies for the long-term 
benefit of a port city. The case studies of two major port cities in China-Guangzhou and Shenzhen, have been conducted. Both port cities have plans and initiatives to enhance their sustainability performances. Policy makers of Guangzhou and Shenzhen have made progress in balancing economic, social, and environmental interests in recent years. While the government pursues the overall target of economic growth, the needs of residents and environmental groups are increasingly addressed. Moving forward, the port cities are recommended to be innovative in exploring new technologies to increase productivity, improve safety, and to reduce negative ecological impacts simultaneously. That is, it is possible to address economic, social, and environmental concerns in a more optimal way. In addition to researchers, the target readers of this paper would be decision-makers with influence over corporate or national policies-corporate organizations and the public sector, i.e., port authorities and national governments. This paper has taken a step forward in the research area, with a view to provide reference to stakeholders and governments in progressing towards sustainability in port cities. Nevertheless, some research limitations exist. This paper has taken a case study method for the in-depth analysis of two Chinese port cities. Due to the nature of this method, results from case studies cannot be generalized to other port cities. Therefore, future research can conduct surveys and other approaches to collect wider data and information. Further research should aim to apply sustainability framework into port city case studies and make comparisons between ports of similar development stage, functions and/or sizes. Also, it would be meaningful to track the sustainability performance of port cities involved in the BRI.

Author Contributions: Conceptualization, J.S.L.L.; Methodology, J.S.L.L.; Formal analysis, J.S.L.L. and W.Y.Y.; Resources, J.S.L.L. and W.Y.Y.; Writing—original draft preparation, J.S.L.L. and W.Y.Y.; Writing-review and editing, J.S.L.L. and W.Y.Y.

Funding: This research received no external funding.

Conflicts of Interest: The authors declare no conflict of interest.

\section{References}

1. Ocampo, J.A. The transition to a green economy: Benefits, challenges and risks from a sustainable development perspective. In Proceedings of the Summary of background papers United Nations Conference on Sustainable Development, Rio de Janeiro, Brazil, 20-22 June 2012.

2. Lam, J.S.L.; Cullinane, K.; Lee, P.T.-W. The 21st-Century Maritime Silk Road: Challenges and Opportunities for Transport Management and Practice. Transp. Rev. 2018, 38, 413-415. [CrossRef]

3. Yap, W.Y. Container Trade and Shipping Connectivity of Vietnam: Implications of Comprehensive and Progressive Agreement for Trans-Pacific Partnership and 21st Century Maritime Silk Road. Int. J. Shipp. Transp. Logist. 2019, 11, 94-116. [CrossRef]

4. Tan, T.Y. Port cities and hinterlands: A comparative study of Singapore and Calcutta. Polit. Geogr. 2007, 26, 851-865. [CrossRef]

5. Kidwai, A.H. Conceptual and methodological issues: Ports, port cities and port-hinterlands. In Ports and Their Hinterlands in India, 1700-1950; Banga, I., Ed.; Manohar Publications: New Delhi, India, 1992; pp. 7-43.

6. Driessen, H. Mediterranean port cities: Cosmopolitanism reconsidered. Hist. Anthropol. 2005, 16, 129-141. [CrossRef]

7. Peris-Mora, E.; Orejas, J.D.; Subirats, A.; Ibanez, S.; Alvarez, P. Development of a system of indicators for sustainable port management. Mar. Pollut. Bull. 2005, 50, 1649-1660. [CrossRef] [PubMed]

8. Fusco Girard, L. Toward a smart sustainable development of port cities/areas: The role of the "Historic Urban Landscape" approach. Sustainability 2013, 5, 4329-4348. [CrossRef]

9. Merk, O.; Ducruet, C.; Dubarle, P.; Haezendonck, E.; Dooms, M. The Competitiveness of Global Port-Cities: The Case of the Seine Axis (Le Havre, Rouen, Paris, Caen)—France; OECD Regional Development Working Papers; OECD Publishing: Paris, France, 2011. [CrossRef]

10. Intervistas. Economic Impact of Port of Prince Rupert. 2017. Available online: https://www.rupertport. com/documents/2017-economic-impact-study/pdf (accessed on 1 February 2018). 
11. Chen, C.; Lam, J.S.L. Sustainability and interactivity between cities and ports: A two-stage Data Envelopment Analysis (DEA) approach. Marit. Policy Manag. 2018, 45, 944-961. [CrossRef]

12. Lundin, M. Indicators for Measuring the Sustainability of Urban Water Systems: A Life Cycle Approach; Chalmers University of Technology: Gothenburg, Sweden, 2003.

13. CSD United Nations Commission of Sustainability Development. Indicators of Sustainable Development: Guidelines and Methodologies; United Nations: New York, NY, USA, 2007.

14. Global Reporting Initiative (GRI). GRI 3.1 Sustainability Reporting Guidelines; Global Reporting Initiative (GRI): Amsterdam, The Netherlands, 2011.

15. Singh, R.K.; Murty, H.R.; Gupta, S.K.; Dikshit, A.K. An overview of sustainability assessment methodologies. Ecol. Indic. 2009, 9, 189-212. [CrossRef]

16. Environment Policy Committee and Directorate, OECD. OECD Core Set of Indicators for Environmental Performance Reviews; OECD: Paris, France, 1993.

17. Warhurst, A. Sustainability Indicators and Sustainability Performance Management; Mining, Minerals and Sustainable Development (MMSD) Project Report; IIED: London, UK, 2002; p. 43.

18. Bossel, H. Deriving indicators of sustainable development. Environ. Model. Assess. 1997, 1, $193-218$. [CrossRef]

19. United Nations Statistics Division. System of Environmental-Economic Accounting Central Framework. 2012. Available online: https://unstats.un.org/unsd/envaccounting/White_cover.pdf (accessed on 12 October 2016).

20. Xiao, Z.; Lam, J.S.L. A systems framework for sustainable development of Port City: Case study of Singapore's policies. Res. Transp. Bus. Manag. 2017, 22, 255-262. [CrossRef]

21. OECD Environment Directorate, Organisation for Economic Cooperation and Development. OECD Key Environmental Indicators; OECD: Paris, France, 2004.

22. Schmeer, K. Stakeholder Analysis Guidelines; World Health Organization: Geneva, Switzerland, 1999.

23. Swanson, E. World Development Indicators 2006; World Bank: Washington, DC, USA, 2006.

24. Dooms, M.; Verbeke, A.; Haezendonck, E. Stakeholder management and path dependence in large-scale transport infrastructure development: The port of Antwerp case (1960-2010). J. Transp. Geogr. 2013, 27, 14-25. [CrossRef]

25. Ravesteijn, W.; He, J.; Chen, C. Responsible innovation and stakeholder management in infrastructures: The Nansha Port Railway Project. Ocean Coast. Manag. 2014, 100, 1-9. [CrossRef]

26. Yin, R.K. Case Study Research: Design and Methods (Applied Social Research Methods); Sage: London, UK; Singapore, 2009.

27. Yin, R.K. Applications of Case Study Research; Sage: Thousand Oaks, CA, USA, 2011.

28. Hörisch, J.; Freeman, R.E.; Schaltegger, S. Applying stakeholder theory in sustainability management: Links, similarities, dissimilarities, and a conceptual framework. Organ. Environ. 2014, 27, 328-346. [CrossRef]

29. Coppens, F.; Lagneaux, F.; Meersman, H.; Sellekaerts, N.; Van de Voorde, E.; van Gastel, G.; Vanelslander, T.; Verhetsel, A. Economic Impact of Port Activity: A Disaggregate Analysis; National Bank of Belgium Working Paper Document; National Bank of Belgium: Brussels, Belgium, 2007.

30. Lam, J.S.L.; Ng, A.K.Y.; Fu, X. Stakeholder management for establishing sustainable regional port governance. Res. Transp. Bus. Manag. 2013, 8, 30-38. [CrossRef]

31. Shanghai International Port (Group). 2017 SIPG Sustainable Development Report; Shanghai International Port (Group): Shanghai, China, 2018.

32. Maritime and Port Authority of Singapore. Sustainability/Integrated Report; Maritime and Port Authority of Singapore: Singapore, 2017.

33. World Port Rankings. Available online: http://www.aapa-ports.org/unifying/content.aspx?ItemNumber= 21048 (accessed on 1 October 2018).

34. JOC. Growth Accelerates at Top Global Ports. Available online: https://www.joc.com/port-news/growthaccelerates-top-global-ports_20180816.html (accessed on 16 August 2018).

35. Wang, J.J.; Slack, B. The evolution of a regional container port system: The Pearl River Delta. J. Transp. Geogr. 2000, 8, 263-275. [CrossRef]

36. Guangzhou Port Authority. Guangzhou Port's “13th Five-Year” Development Ideas 2016. Available online: http:/ / www.gzport.gov.cn/gzsgwj/ghjh/201611/4f89fe9df8c04eeb947a6c65f4dff586.shtml (accessed on 5 July 2018). (In Chinese) 
37. Draft of the “Guangzhou City Master Plan (2017-2035)”. 2018. Available online: http:/ /money.163.com/18/ 0225/08/DBFQE6SB00258105.html (accessed on 5 July 2018). (In Chinese)

38. Lam, J.S.L.; Yap, W.Y. Container port competition and complementarity in supply chain systems: Evidence from the Pearl River Delta. Marit. Econ. Logist. 2011, 13, 102-120. [CrossRef]

39. Huang, L. Research on the Change of Shenzhen City Master Planning and Development Strategy. 2016. Available online: http:/ / www.cnki.com.cn (accessed on 5 July 2018). (In Chinese)

40. National Development and Reform Committee. Outline of the Reform and Development Plan of the Pearl River Delta Region (2008-2020); National Development and Reform Committee: Beijing China, 2008.

41. Shenzhen Municipal Transportation Committee; Shenzhen Development and Reform Commission; Shenzhen Planning and Land Resources Committee. Notice on Printing and Distributing the 13th Five-Year Plan for Comprehensive Transportation Plan in Shenzhen. 2017. Available online: http:/ /www.sz.gov.cn/zfgb/ 2017/gb998/201703/t20170327_6096630.htm\# (accessed on 6 July 2018). (In Chinese)

42. Kemme, N. Effects of storage block layout and automated yard crane systems on the performance of seaport container terminals. OR Spectr. 2012, 34, 563-591. [CrossRef]

43. Zhang, W.; Lam, J.S.L. Maritime cluster evolution based on symbiosis theory and Lotka-Volterra model. Marit. Policy Manag. 2013, 40, 161-176. [CrossRef]

44. PIANC. Sustainable Ports: A Guide for Port Authorities; PIANC: Bruxelles, Belgium, 2014.

45. Di Vaio, A.; Varriale, L. Management Innovation for Environmental Sustainability in Seaports: Managerial Accounting Instruments and Training for Competitive Green Ports beyond the Regulations. Sustainability 2018, 10, 783. [CrossRef]

46. Di Vaio, A.; Varriale, L.; Alvino, F. Key performance indicators for developing environmentally sustainable and energy efficient ports: Evidence from Italy. Energy Policy 2018, 122, 229-240. [CrossRef]

47. Lee, P.T.-W.; Lam, J.S.L.; Lin, C.W.; Hu, K.C.; Cheong, I. Developing the Fifth Generation Port concept model: An empirical test. Int. J. Logist. Manag. 2018, 29, 1098-1120. [CrossRef]

(c) 2019 by the authors. Licensee MDPI, Basel, Switzerland. This article is an open access article distributed under the terms and conditions of the Creative Commons Attribution (CC BY) license (http:/ / creativecommons.org/licenses/by/4.0/). 